\title{
Investigating the Development of Individuals with Mental and Physical Problems Receiving Water Therapy in a Special Education and Rehabilitation Center
}

\author{
Ahmet Şirinkan (Corresponding author) \\ Department of Recreation, Faculty of Sports Sciences, Atatürk University, Erzurum, Turkey \\ E-mail: asirinkan@atauni.edu.tr
}

Received: November 5, 2021 Accepted: December 8, 2021

Published: December 31, 2021

doi:10.5296/jei.v7i3.19156 URL: https://doi.org/10.5296/jei.v7i3.19156

\begin{abstract}
Investigation of the physical and psychological development challenged individuals receiving water therapy in a private education rehabilitation center. The aim of this study is to investigate the physical and psychological development challenged individuals receiving water therapy in a private education rehabilitation center.

5 children with mentally and physically problems who took water therapy in the Special Education Rehabilitation Center participated in the study. Children aged between 3-8. Children who have mentally problematic, who have participated in the research, have severe, moderate and mild mental problems and who have problems physically also have placenta, quatri plaque, spina bifida etc. children with orthopedic insufficiency.

Special mobility training program was prepared for the children to be able to make joint problems for children with mental problems and physical problems. While the program was being prepared, support was received from special educator, water therapist and repertoire people.

The study was administered 4 months, 2 days a week and 60-90 minutes. At the beginning of the research, the children who had mental problems were afraid of entering the water, they did not comply with the commands, they did not want to be separated from the mother and father.
\end{abstract}

At the end of the research process, children with mental problems enter the water 
comfortably and even hurry to enter, they are not afraid of water, they are more adaptable to the commands, they continue to work separately from their parents, they are more willing to enter the water in children who have problems with orthopedic problems. It was observed that most of the children who wanted to move in the water, they were mostly able to perform the movements, and the majority of the children (90\%) who had walking pants had walking exercises.

Keywords: Water therapy, Special education, Rehabilitation

\section{Introduction}

As it is known, sports is a necessary effort for a healthy and happy life and is important for all people. However, sport has a different importance for the disabled persons. Because sports can open a new window for disabled individuals who have already faced many obstacles in their lives and live with the stress created by these obstacles (Özer, 2001). Due to various reasons, mentally retarded children cannot find the physical activity opportunities necessary for the use and development of large and small muscle groups. However, a great contribution can be made to their developmental characteristics through physical activities that they can participate in from pre-school periods. Physical education and sports classes are the best environment where they can catch physical activity opportunities with school age (Yildiz et al., 2011). Regardless of the type and degree of disability, moving, exercising and participating in sports activities give happiness to the individual. The pleasure of moving is an important tool in meeting the individual's needs for fun and success, and it also increases the motivation for life. Sports contribute to the social integration of the disabled by providing their physical, mental and social development (Eichsteadt \& Lavay, 1995). It is an undeniable fact that individuals with disabilities who are directed to sports will have a positive development in their physical and physiological capacities while accelerating their adaptation to society. The problems experienced by disabled people are not only a problem of the disabled, but also a problem of their environment, their families and all members of the society (Butterfield \& Ersing, 1986; Siegel, Marchetti, \& Tecklin, 1991). In many studies, it has been reported that the muscle strength of individuals with intellectual disabilities is lower than individuals without intellectual disability (Pitetti \& Yarmer, 2002). Also, when they do not do a physical activity, they cannot show enough motivation and get bored quickly (Winnick, 1995; Stadler \& Pitetti, 1996).

In inclusive schools, all pupils should have opportunities to participate continually andmeaningfully in school activities at all levels. Thus, being physically integrated into aschool is not sufficient to ensure full participation (Vetoniemi \& Kärnä, 2021). Indicators of the existence of partici-pation provide no information on its extent or quality. In the context of inclusive edu-cation, this has been acknowledged as a significant shortcoming (Pijl, Frostad, \& Flem2008; Vetoniemi \& Kärnä, 2021).

\section{Method}

Five (5) mentally and physically problematic children who received water therapy in a special education rehabilitation center participated in the research. The children are between 
the ages of 3-8. Children with mental problems participating in the research are severe, moderate and mild, and children with physical problems are plagio, quatri, spina bifida, etc. children with orthopedic deficiencies. For the research, a special movement training program was prepared for children who have mental and physical problems. While preparing the program, support was received from special educators, water therapists and recreation specialists. The research was carried out for 4 months, 2 days a week and 60-90 minutes. At the beginning of the study, it was observed that the children with mental problems were afraid of entering the water, did not obey the commands and want to leave their parents, while it was observed that the children with orthopedically problems were also afraid of entering the water, constantly waiting for help, and afraid to move in the water without help.

\section{Result}

Table 1. Special movement education program applied in the research

\begin{tabular}{|c|c|c|c|}
\hline Weeks & Days & Aim & Gains \\
\hline \multirow[b]{2}{*}{1} & Saturday & Out of the pool walking, running, splashing. & Balanced walking, running and jumping. \\
\hline & Sunday & Out of pool holding, grasping, throwing. & $\begin{array}{l}\text { Ability to hold, grasp and throw objects accurately } \\
\text { and firmly. }\end{array}$ \\
\hline \multirow[b]{2}{*}{2} & Saturday & Poolside walking, running, splashing. & Balanced walking, running and jumping. \\
\hline & Sunday & Poolside holding, gripping. & $\begin{array}{l}\text { Ability to hold, grasp and throw objects accurately } \\
\text { and firmly. }\end{array}$ \\
\hline \multirow{2}{*}{3} & Saturday & Out of teh pool walking, running, splashing. & $\begin{array}{l}\text { To be able to hold, control and throw balls of different } \\
\text { sizes and weights. }\end{array}$ \\
\hline & Sunday & Out of pool holding, grasping, throwing. & $\begin{array}{l}\text { To be able to hold, control and throw balls of different } \\
\text { sizes and weights with both hands and feet. }\end{array}$ \\
\hline \multirow{2}{*}{4} & Saturday & Poolside walking, running, splashing. & $\begin{array}{l}\text { To be able to hold, control and throw balls of different } \\
\text { sizes and weights. }\end{array}$ \\
\hline & Sunday & Poolside holding, gripping. & $\begin{array}{l}\text { To be able to hold, control and throw balls of different } \\
\text { sizes and weights with both hands and feet. }\end{array}$ \\
\hline \multirow{2}{*}{5} & Saturday & Out of teh pool walking, running, splashing. & $\begin{array}{l}\text { To be able to roll, climb, walk in balance, bounce in a } \\
\text { balanced and smooth manner. }\end{array}$ \\
\hline & Sunday & Out of pool holding, grasping, throwing. & $\begin{array}{l}\text { Ability to roll, climb, walk in balance, and bounce } \\
\text { with balance and smoothness. }\end{array}$ \\
\hline \multirow{2}{*}{6} & Saturday & Poolside walking, running, splashing. & $\begin{array}{l}\text { To be able to roll, climb, walk in balance, bounce in a } \\
\text { balanced and smooth manner. }\end{array}$ \\
\hline & Sunday & Poolside holding, gripping. & $\begin{array}{l}\text { Ability to roll, climb, walk in balance, and bounce } \\
\text { with balance and smoothness. }\end{array}$ \\
\hline
\end{tabular}




\begin{tabular}{|c|c|c|c|}
\hline \multirow{2}{*}{7} & Saturday & Walking, running, jumping in the pool. & $\begin{array}{l}\text { To be able to perform the skills specific to sports } \\
\text { branches in accordance with their technique in water. }\end{array}$ \\
\hline & Sunday & Holding, grasping, throwing in the pool. & $\begin{array}{l}\text { To be able to perform the skills specific to sports } \\
\text { branches in accordance with their technique in water. }\end{array}$ \\
\hline \multirow{2}{*}{8} & Saturday & Walking, running, jumping in the pool. & $\begin{array}{l}\text { To be able to perform the skills specific to sports } \\
\text { branches in accordance with their technique in water. }\end{array}$ \\
\hline & Sunday & Holding, grasping, throwing in the pool. & $\begin{array}{l}\text { To be able to perform the skills specific to sports } \\
\text { branches in accordance with their technique in water. }\end{array}$ \\
\hline \multirow{2}{*}{9} & Saturday & Walking, running, jumping in the pool. & $\begin{array}{l}\text { To be able to hold, control and throw balls of different } \\
\text { sizes and weights in water with both hands and feet. }\end{array}$ \\
\hline & Sunday & Holding, grasping, throwing in the pool. & $\begin{array}{l}\text { To be able to roll, climb, walk in balance and bounce } \\
\text { in the water in a balanced and smooth way. }\end{array}$ \\
\hline \multirow{2}{*}{10} & Saturday & Walking, running, jumping in the pool. & $\begin{array}{l}\text { To be able to perform the skills specific to sports } \\
\text { branches in accordance with their technique in water. }\end{array}$ \\
\hline & Sunday & Holding, grasping, throwing in the pool. & $\begin{array}{l}\text { To be able to play games in the water as a couple and } \\
\text { as a group and to obey the rules. }\end{array}$ \\
\hline \multirow{2}{*}{11} & Saturday & Walking, running, jumping in the pool. & $\begin{array}{l}\text { To be able to play games in the water as a couple and } \\
\text { as a group and to obey the rules. }\end{array}$ \\
\hline & Sunday & Holding, grasping, throwing in the pool. & $\begin{array}{l}\text { To be able to play games in the water as a couple and } \\
\text { as a group and to obey the rules. }\end{array}$ \\
\hline \multirow{2}{*}{12} & Saturday & Walking, running, jumping in the pool. & $\begin{array}{l}\text { To be able to play games in the water as a couple and } \\
\text { as a group and to obey the rules. }\end{array}$ \\
\hline & Sunday & Holding, grasping, throwing in the pool. & $\begin{array}{l}\text { To be able to play games in the water as a couple and } \\
\text { as a group and to obey the rules. }\end{array}$ \\
\hline
\end{tabular}

\section{Discussion}

At the beginning of the study, children with mental and physical problems exhibited behaviors that were afraid of going into the water, did not obey the commands, and did not want to be separated from their parents. As the practices progressed, it was observed that they entered the water comfortably and even rushed to enter, they were not afraid of water, they obeyed the commands more, and they continued to work separately from their mother and father. It has been observed that children with orthopedically problems enter the water more willingly, they want to move in the water without waiting for help, they can mostly do the movements shown, and the majority of the children (90\%) who has walking problems can do walking exercises. In scientific studies, it is seen that individuals with learning difficulties provide physical, social and mental developments with sportive activities and exercise programs (Ün et al., 2001). Rimmey and Kely (1991) found a significant increase in knee 


\section{Macrothink

flexion-extension muscle strength as a result of the physical fitness training they performed for mentally retarded children aged 11-18.

Özmen and Yıldırım (2011) observed a significant improvement in lower extremity muscle strength with the weight training they had done. They stated that the strength training program for these individuals should include activities that the person enjoys, that are progressive, individually planned, and target special muscle groups in the trunk, arms and legs.

Azeem and Ameer (2011) stated in their study that the physical and motor performances of students with disabilities begin at an early age and this further increases their success. In addition, they did not find a significant difference between male and female students in terms of development.

Özbar and Kayapınar (2006) stated in their research on pre-school children that a six-month movement training program created significant improvements in children's hand-eye coordination. In the study of Niekerk et al. (2018), empirical studies should set out appropriately to test the developed models, and this information should feed the process of adjusting and updating the developed models.

\section{Conclusion}

As a result, it can be said that the movement training program with exercise and sports content applied to children with disabilities provides positive developments in children, improvements in coordination hand skills and especially in strength development. On the other hand literature on the effects of exercise interventions in indi-viduals with ASD showed that motor skill learning is use-ful for improving motor outcomes and functional capacities and also suggested that it can be helpful for improving behavioural, cognitive and social difficulties (Caputo et al., 2018). However, qualitative studies are still insufficient in terms of quality. For development, researchers and politicians should make better investments in the subject and develop new methods for development (Van der Watt et al., 2018).

\section{References}

Azeem, K., \& Ameer, A. A. (2011). Physical and Performance Profiles of Athletes with Physical Disabilities. Science Journal of Physical Education and Sports, 26-30.

Butterfield, S. A., \& Ersing, W. F. (1986). Influence of age, sex, hearing loss and balance performance by deaf children. Percept. Mot. Skills., 62(2), 659-63. https://doi.org/10.2466/ pms.1986.62.2.659

Caputo, G., Ippolito, G., Mazzotta, M., Sentenza, L., Muzio, M. R., Salzano, S., \& Conson, M. (2018). Effectiveness of a multisystem aquatic therapy for children with autism spectrum disorders. Journal of Autism and Developmental Disorders, 48(6), 1945-1956. https://doi.org/ 10.1007/s10803-017-3456-y

Eichsteadt, C. B., \& Lavay, B. W. (1995). Physical Activity for Individuals with Mental Retardation (p. 47). Compaign, Illinois. 
Özbar, N., \& Kayapına, F. (2007). Okulöncesi Dönemde Çocukların Hareket Eğitiminin El-Göz Koordinasyonu Süresi ve Hata Sayısına Etkisi. Beden Eğitimi ve Spor Bilimleri Dergisi, 8(4), 40-48.

Özer, D. S. (2001). Engelliler İçin Beden Eğitimi ve Spor, Nobel Yayın Dağıtım, Ankara.

Özmen, T., \& Yıldırım, N. Ü. (20011). Zihinsel Engelli Çocuklarda interval Antremanın Alt Ekstremite Kas Kuvvetine Etkisi. Beden Eğitimi ve Spor Bilim Dergisi, 26-30.

Pijl, S. J., Frostad, P., \& Flem, A. (2008). The Social Position of Pupils with Special Needs in RegularSchools. Scandinavian Journal of Educational Research, 52, 387-405. https://doi.org/ $10.1080 / 00313830802184558$

Pitetti, K. H., \& Yarmer, D. A. (2002). Lower Body Strength of Children and Adolescents With and Without Mild Mental Retardation. Adapted Physical Activity Quarterly, 19(1), 68-81. https://doi.org/10.1123/apaq.19.1.68

Rimmer, J. H., \& Kelly, L. E. (1991). Effect of Resistance Training Program on Adult with Mental Retardation. Adapted Physical Activity Quarterly, 8, 146-153. https://doi.org/10.1123/ apaq.8.2.146

Siegel, J. C., Marchetti, M., \& Tecklin, J. S. (1991). Age-related balance changes in hearing-impaired children. Phys. Ther., 71(3), 183-9. https://doi.org/10.1093/ptj/71.3.183

Stadler, L. V., \& Pitetti, K. H. (1996). Isometric and Isokinetic Leg Strength of Youth with and without Mental Retardation. Med Sci Sports Exercies, 28, 49. https://doi.org/10.1097/ 00005768-199605001-00049

Un, N., Erbahçeci, F., \& Ergun, N. (2001). Effect of Physical Fitness Training on Physical Fitness Parameters in Mentally Retarded Children. Fizyoterapi Rehabilitasyon, 16(1), 16-21.

Van der Watt, A. S. J., Van de Water, T., Nortje, G., Oladeji, B. D., Seedat, S., \& Gureje, O. (2018). The perceived effectiveness of traditional and faith healing in the treatment of mental illness: A systematic review of qualitative studies. Social Psychiatry and Psychiatric Epidemiology, 53(6), 555-566. https://doi.org/10.1007/s00127-018-1519-9

Van Niekerk, K., Dada, S., Tönsing, K., \& Boshoff, K. (2018). Factors perceived by rehabilitation professionals to influence the provision of assistive technology to children: A systematic review. Physical \& Occupational Therapy in Pediatrics, 38(2), 168-189. https://doi.org/10.1080/01942638.2017.1337661

Vetoniemi, J., \& Kärnä, E. (2021). Being included-experiences of social participation of pupils with special education needs in mainstream schools. International Journal of Inclusive Education, 25(10), 1190-1204. https://doi.org/10.1080/13603116.2019.1603329

Winnick, J. P. (1995). Adapted Physical Education and Sport (2nd ed.). Champaign, IL: Human Kinetics. 


\section{Macrothink}

Journal of Educational Issues ISSN 2377-2263

2021, Vol. 7, No. 3, Special Issue

Yıldız, Ö., Yıldız, M., Çetin, M. Ç., \& Uslu, S. (2011). Öğretilebilir Zihin Engelli Okullarında Beden Eğitimi Dersleri Yürüten Öğretmenlerin Karşılaştıkları Problemler ve Çözüm Önerileri. Beden Eğitimi ve Spor Bilim Dergisi, 126-135.

\section{Copyright Disclaimer}

Copyright for this article is retained by the author(s), with first publication rights granted to the journal.

This is an open-access article distributed under the terms and conditions of the Creative Commons Attribution license (http://creativecommons.org/licenses/by/3.0/). 